\title{
Integrated Management System as a Tool to Improve Corporate Sustainability Performance in the Pharmaceutical Manufacturing Industry in Indonesia
}

\author{
Erwin $^{1}$, Dodi Wirawan Irawanto ${ }^{2, *}$ \\ ${ }^{1}$ Engineering Department, Universitas Darma Persada, Indonesia \\ ${ }^{2}$ Management Department, Faculty of Economics and Business, Universitas Brawijaya, Malang, Indonesia \\ *Corresponding author.Email : dodi.wi@ub.ac.id
}

\begin{abstract}
The pharmaceutical manufacturing industry in Indonesia is marked with tough competition that requires the relevant parties in this industry to implement integrated management systems. Despite the case, only around $50 \%$ of the largest 15 pharmaceutical companies in Indonesia have been implementing this integrated management system. This study aimed to analyze the direct impact of the implementation of an integrated management system on the sustainability performance of companies and to develop a model to increase the achievement of corporate sustainability performance through the implementation of an integrated management system. This study conducted an in-depth analysis on the phenomenon of business and do a literature review on conceptual and empirical articles related to the impact of the implementation of an integrated management system on corporate sustainability performance. The findings showed that all the resources within an organization are the aspects that must be managed optimally in order to make the business process effective and improve sustainability in achieving the organization's targets related to the aspects of social, economy and environment. The implementation of integrated management system contributes to the level of requirement fulfillment of the relevant parties, process efficiency, reduction of negative environmental impacts and competitiveness in supporting the achievement of corporate sustainability performance.
\end{abstract}

Keywords: Corporate sustainability, Integrated management system, Pharmaceutical manufactures, Indonesia

\section{INTRODUCTION}

The global pharmaceutical industry which comprises thousands of companies, such as, in the field of biotechnology or biotech, producers of generic drugs, and organizations that conduct research and development, continues to make innovations. The sales growth drops because the sales of branded drugs increase which results from a growing need for more affordable generic drugs [1]. As a part of the global industrial sector that has a huge interest, the global pharmaceutical industry is endeavoring to intensify its development, production and marketing activities. The contribution of the pharmaceutical industry's revenues globally exceeded one trillion US dollars in 2014 [2].

The pharmaceutical industry sector in Indonesia is a sector which is full of requirements for strong industrial basic knowledge. In 2005, the pharmaceutical industry in Indonesia paid little attention to product development, and only focused on obtaining licenses from foreign entities [1]. Compared to the condition in the US or other western countries, regulations related to the pharmaceutical industry in Indonesia are not as strict as in those countries but continued to be developed for better improvement. This is the reason why producers can compete in Indonesia's pharmaceutical industry market [3]. 
Presently, the pharmaceutical manufacturing industry in Indonesia plays the role as one of the industries that triggers the growth of the national manufacturing industry [4]. The pharmaceutical industry sector began to grow in 1966, and from years 2007 to 2013 it grew to $85 \%$ [3]. The pharmaceutical industry is a labor-intensive industry and is marked with tough competition. With such potential, the national pharmaceutical industry is expected to be competitive in the global market. The fact that the market share of multinational pharmaceutical companies is small as the product priority is for export indicates that the challenges ahead for the national industry are global competition. As the global pharmaceutical industry is included in the "highly regulated" industry, one of the international standards that must be complied with by the national pharmaceutical industry is the application of an integrated management system. Based on data in the year 2016 from the Pharma Board Room, of 15 large national and multinational pharmaceutical companies in Indonesia, $50 \%$ of them have implemented an integrated management system.

Based on data from one of the pharmaceutical industries in Indonesia that has implemented the integrated quality, environment, occupational health and safety system for more than 3 (three) years, the achievement level of corporate sustainability performance varies. Three main points of its application are among others achievement of performance related to quality performance, environmental performance, social performance that must be reviewed further for effective implementation of integrated management system so as to solve problems in the pharmaceutical industry [5]. Integrated management system is an integration of the requirements of quality, environment, occupational health and safety management system. The integrated management system is applied commencing from the stages of planning, implementation, inspection and action in each part of the organization to fulfill the expectation of the relevant parties to improve the performance [6-8]. Fulfillment of expectation and needs of the relevant parties or the stakeholders related to the aspects of synergized economy, social and environment is an effort to maintain corporate sustainability and improve the performance of corporate sustainability $[9,10]$.

Integration of the quality, environment, occupational health and safety management system must absolutely be strengthened by fulfilling the expectation of the involved stakeholders. As in Barney [11], who maintains that all assets, capacity, capability, organizational process, the company' attribute, knowledge and information are a part of the company' resources that must be comprehended and applied as a strategy to improve the efficiency and effectiveness of processes in the organization, which is known as the theory of resources. Studies by Bozbura et al. [12], found three aspects of capital consisting of humans (individual knowledge level owned by every employee), organization (the creative capacity of the organization), and relation (management of the company's relation with its environment). Lacked development of the three capital resources causes failed good governance in company organizations in Indonesia in operating optimally, and they often encounter many failures in competing locally/nationally or globally [13].

The benefits enjoyed by companies in applying integrated management system are still very minimum and do not guarantee the achievement of productivity in the company organization [14-17]. Lacked implementation of the ISO standard based-quality and environment management system is influenced by more specific pharmaceutical industry's requirements such as Good Manufacturing Practice and lacked encouragement from the stakeholders in the implementation of other management systems [18]. This is reinforced by studies carried out by Gianni et al. [19] which shows that the implementation of an integrated management system supports the achievement of corporate sustainability performance and depends on the resources and the level of management system applied.

Gianni et al. [19] highlight that there have been many company organizations integrating their management systems and complying with the principle of corporate sustainability to achieve their business objectives in fulfilling the needs and expectations of the stakeholders. Previous study has focused on companies that have sensitivity to the life quality of their customers [20]. This review is for a more in-depth development and further study on the role of integrated management system in the achievement of corporate sustainability performance particularly in the industry of pharmaceutical manufacturing.

\section{LITERATURE REVIEW}

\subsection{Integrated Management System}

Several experts express their opinion on an integrated management system, such as: coordination of several 
requirements so as to have the same direction [6], an integrated management system which enhances the organization's performance [7]. A series of connected processes from the various similar resources to achieve the objectives related to compliance with the requirements of the stakeholders [8], systematic approaches to comply with standard requirements [21], and integrating the management system through the process of planning, observation, quality control, environment and safety [22] Integrated management system is a method to minimize risks so that the organization can be more efficient [23]. Based on the above studies, it can be concluded that an integrated management system is coordination of requirements of the quality, environment, occupational health and safety management system in order to make the stages of process approach efficient starting from the stage of planning in formulating the policies and objectives of organizations, implementation and control of the process, monitoring and actions required to review the effectiveness of the implementation of integrated management system.

\subsubsection{Integrated Management Program}

Based on a study carried out by Hamidi et al. [15], an integrated management program can lower the accident rate and affects the personnel attitude and work satisfaction through occupational safety programs, and through ideas from employees related to the issues of quality, environment, occupational health to boost the company's reputation [24]. Several contexts of studies above suggest that the implementation of integrated management programs in the context of sustainability improvement in several business processes may, with proper action plan, benefit the achievement of the performance of integrated management system and effective implementation, so as to increase the achievement of corporate sustainability performance.

\subsubsection{Commitment of Integrated Management}

Research by Santos et al. [25] indicates that the relation between the implementation of Total Quality Management and the occupational health and safety management system may give inputs to organizations to have a higher commitment to the management of environment, development and innovation, and facilitate management of risk assessment process, accountability and training, interaction with the implementation of occupational health and safety management system in companies that have adopted very high Total Quality Management. Based on the result of the research above, the management commitment is an inseparable part of the organization that applies an integrated management system to achieve corporate sustainability performance supported by the management's involvement to encourage achievement of performance to improve the business process internally or externally and to follow up on the expectation and needs of the stakeholders through a commitment to the implementation of integrated management system.

\subsubsection{Internal Audit on Integrated Performance}

The studies by Rebelo et al. [26] maintain that improvement and innovation have been performed through integrated audits in various organization areas, including suppliers and subcontractors. Another highlighted aspect is through optimizing resources, improving integrated coordination on risk management, product quality and environment, reducing internal and external audits. Change of approaches in management process requires a method to do assessment particularly on the implementation of the audit by auditors through new approaches [27]. Several studies above conclude that an integrated internal audit program between the quality management system, environment, and occupational health and safety has an audit focus on achievement of process performance and supports the achievement of corporate sustainability performance.

\subsubsection{Integrated Management Review}

The studies conducted by Rebelo in 2014 maintain that management review needs to be carried out to ensure that all the requirements of an integrated management system are appropriate, effective and efficient for sustainable improvement. Sustainable improvement of the performance of global organizations must always have the perspective of sustainable objectives. The model developed from integration of the quality, environment, occupational health and safety management system within the organization must prioritize each stage such as planning, implementation, inspection and action [26]. Several aspects that need to be observed in the integration of management system are measured performance, 
guidelines on integrated audit, policies, trainings, management review, management change, strengths and weaknesses during the integration process, review focus on fulfillment of the requirements and performance as these may potentially provide opportunity of sustainable improvement.

\subsection{Corporate Sustainability Performance}

According to Artiach et al. [10], in the business context, "corporate sustainability" is the ability to perform sustainable development. Through corporate sustainability performance, an organization can accommodate the needs and expectation of the stakeholders and ensure that the company keeps its assets of resources and profits in a short or long term. According to Rebelo et al. [26], the need of global business related to the requirements of the stakeholders and the management system standard must be continuously taken into account by the organization. The implementation of an environment management system constitutes a framework that can improve the organization's performance through process efficiency, cost saving, promotion of companies' image, and may finally give contribution in the economic aspect. This is also supported by a positive relationship between the environmental performance and economic performance $[28,29]$.

Research by Souza et al. [30] proves that the implementation of lean integrated management system gives positive contribution to the achievement of corporate sustainability performance, through several structured measures and applied effectively, one of which is the aspect of the environment, by reducing uses of materials, energy consumption and efficiency, and total volume of recycled water. Through the implementation of environment management system, an organization may give a contribution to supporting the company's economic growth, creating competitiveness, financial profits and minimizing the negative impacts of the organization's activities on the environment [27].

Based on several researches above, it is concluded that corporate sustainability performance is an effort made to maintain the sustainability of companies through approaches applied to the aspects of economy, social and environment which run in synergy to produce a measured achievement in fulfilling the expectation and needs of the stakeholders. Through the stages of approaches, planning process, implementation, inspection and effective action, the implementation of integrated management system contributes to fulfillment of requirements, process efficiency, minimized negative environment impacts and the organization's competitiveness to improve corporate sustainability performance.

\section{RESEARCH METHOD}

The purpose of this review is to analyze the direct impact of the implementation of integrated management system on corporate sustainability performance and develop a model to enhance the achievement of corporate sustainability performance through the implementation of integrated management system. The initial stage taken in this research is to find articles relevant to integrated management system and corporate sustainability performance, then discuss the referred researches related to the substances of research discussed, search issues which are pro and against the topic discussed, then develop a hypothetical model and conceptual and empirical research for further studies [30].

Articles searched in the last 33 years were collected as references from various sources of scientific databases such as: Elsevier, Google Scholar, Emerald, Springer and Sage Publications, Scopus, ProQuest. The author used the keywords used such as, integrated management system, quality management system, environment management system, occupational health and safety management system, corporate sustainability performance, to search related articles to be followed up in the discussion.

\section{RESULT OF REVIEW}

Some empirical studies relevant to corporate sustainability suggest that further studies are needed to develop a model to measure the performance of an integrated management system to improve the performance of an organization [14]. The research by Rebelo et al. [26], suggests that further research is required to test the implementation of integrated management system to fulfill the needs and expectation of the stakeholders. To support the result of its research Hamidi et al. [15] recommends that further researches may analyze cases of effective implementation of integrated management system in achieving organizations' performance from various types of industry. This is strengthened by the result of research by Massoud et al. [18] in 2015 which explains that the 
government's involvement and lacked knowledge are the factor that causes the pharmaceutical industry to only focuses on quality management system (Good Manufacturing Practice). The above theoretical and empirical studies reveal the importance of corporate sustainability in maintaining the existence of companies through measurement of the performance process of the implementation of integrated management system, fulfillment of the need and expectation of the stakeholders, and the effectiveness of implementation of integrated management system for a long run in supporting the achievement of corporate sustainability performance.

One of the strategies to implement the quality, environmental, occupational health and safety management system efficient is through the integration of requirements of the management system. Consistency in the implementation of integrated management system is a difficult thing to do by organizations in achieving their performance. Another aspect that some organizations that have applied the quality, environment, occupational health and safety management system are not aware of is that through the implementation they indirectly contribute to the company's sustainability program. An integrated management system must further be examined to identify its impact on the achievement of corporate sustainability performance, and to get a appropriate strategy. Quality Performance, environmental performance and social performance contribute to corporate sustainability program and constitute a part of the strategy to improve the sustainability performance of companies. Effective application of integrated management system will create an advantage for the pharmaceutical industry in Indonesia in facing national and global competition.

\section{DISCUSSION}

All resources in an organization are the aspect that must be optimally managed in order to make the business process effective and enhance sustainability in achieving the organization's targets related to the social, economic dan environmental aspects, through synergy with reliable organizations, competent human resources and strong relationships with the stakeholders [11, 12, 31-36]. Integrated management system serves as a tool to coordinate the requirements in the quality, environment, occupational health and safety management system to make stages of process approaches efficient starting from the stage of planning in determining the organization's policies and objectives, implementation and control of the process, observation and action needed to review the effectiveness of implementation of integrated management system [6-8, 21-23]. From several researches above, we can make a concept that improved the implementation of integrated management system may enhance the corporate sustainability performance. This concept needs to be proven with empirical studies in the pharmaceutical manufacturing industry in Indonesia.

To strengthen the construction of a concept in the implementation of an integrated management system it is necessary to develop several items as follows:

1. Preparation of work programs in the company organization refers to the objective which involves the aspects of quality, environment, occupational health and safety [14, 15, 20, 24, 38-44].

2. Management of integrated management system is supported by the management commitment through the involvement of the management and demonstration of all activities to achieve the effectiveness of integrated management system [7, $15,16,35,25-27,39,40,43-48]$.

3. Internal audit on integrated performance is a process of assessment and evaluation to improve the effectiveness of the organization's business process and performance [16, 20, 26, 27, 39, 40].

4. Management review on integrated performance is an attribute in achieving the objective and performance of an organization, as well as the conformity with the requirements of integrated management system, effectiveness and sustainable improvement $[14,26$, $39,40,46]$

For the need of this research and the result of research by Gianni et al. [19], the implementation of integrated quality, environment, occupational health and safety management system and corporate sustainability performance may become a strong relationship through implementation of management theory, and the level of implementation of integrated management system and resources becomes the main factor in applying the management theory, particularly in creating a performance design for corporate sustainability. In achieving the corporate sustainability performance we need to have a clear understanding on the framework of concept of corporate sustainability and the need for ideas 
related to the stakeholders, requirements concerning environmental preservation and consideration of the implementation of the whole system in the company organization [42]. Corporate sustainability performance is a measured result that is intended to be achieved in the implementation of corporate sustainability program [10]. The construction of a concept that supports the achievement of corporate sustainability performance is as follows:

1. Fulfillment of the requirements of stakeholders which is fulfillment of the need and expectationa of the stakeholders [20, 26-28, 30, 39, 40].

2. Process efficiency is efficiency in terms of raw material consumption, resources in the control of operation $[11,26,28,30]$.

3. Reduction of environmental impacts which is changes to the environment, whether detrimental or beneficial, the entirety or a part thereof is caused by the environment aspect (activities or products/services of an organization interacting with the environment of another organization) [27, 30, 40, 47].

4. Creating competitiveness which is the company's reputation that gives added value $[14,17,24,27,43]$.

Based on the description from several conceptual definitions above, the author summarizes the explanation in a construct model containing the research model and the forming items. The model construct is illustrated as a strategic model in the implementation of an effective integrated management system in increasing the achievement of corporate sustainability performance, as shown in Figure 1.

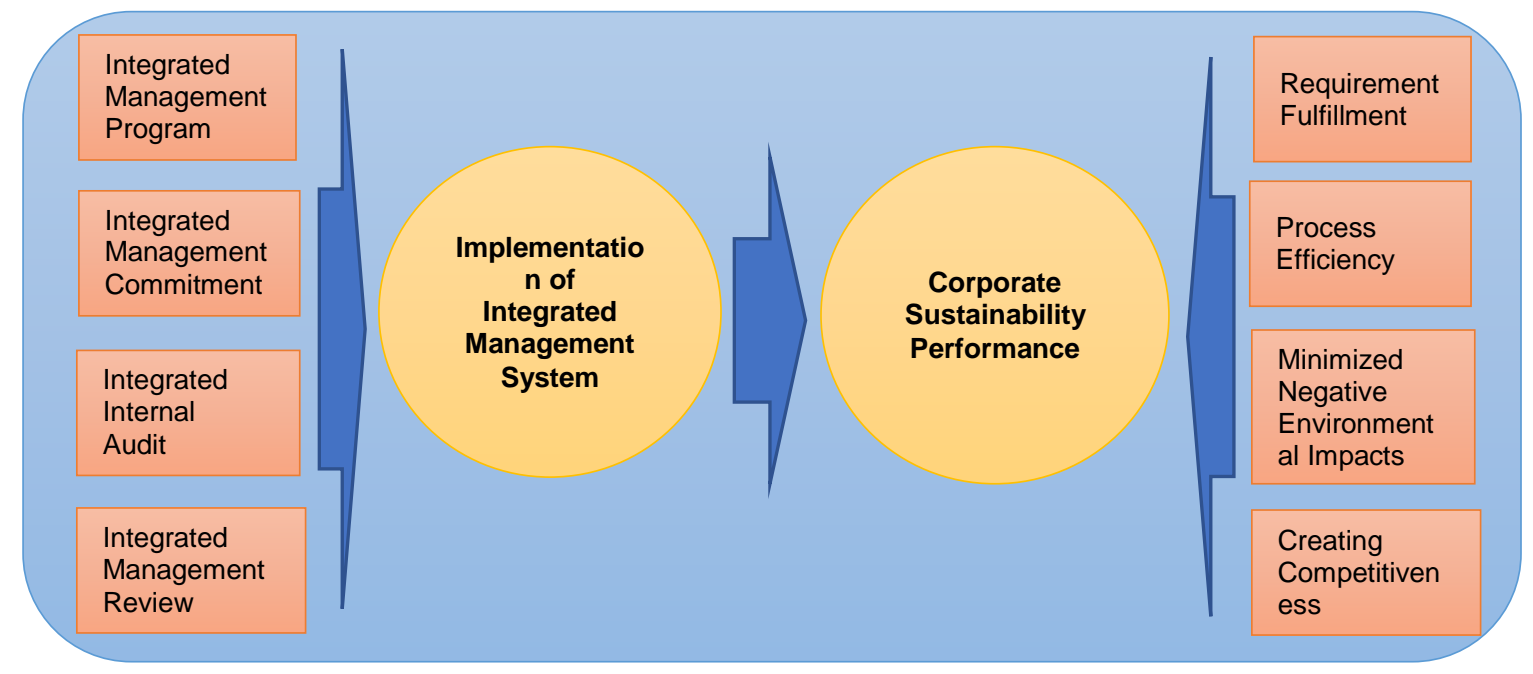

Figure 1 Construct of research model

The proposed model construct above clarifies that the implementation of integrated management system supported by integrated management program, management commitment, internal audit and management review has positive relation to increase the achievement of corporate sustainability performance supported by fulfillment of requirements, efficiency process, minimized negative environmental impacts and creating competitiveness.

\section{CONCLUSION}

This research produces a model construct which is interrelated between the implementation of integrated management systems in achieving corporate sustainability performance. The implementation of an effective management system is supported by an integrated management program, strong management commitment, the 
implementation of an integrated internal audit on performance, and review on integrated performance management. In addition to implementation of effective integrated management system in achieving corporate sustainability performance, there are other support aspects from the fulfillment of requirements, efficiency process, minimized negative environment impacts and creating competitiveness, so that this model construct can suggest strategic measures for the pharmaceutical manufacturing in Indonesia to increase its the achievement of corporate sustainability performance.

The result of this research is a model construct of research which certainly needs further analysis as to the direct impact of the implementation of integrated management system on the achievement level of sustainability performance through empirical research in the sector of manufacturing industry such as pharmaceutical manufacturing, electronics, automotives, foods and beverages companies, and the service sector such as distribution of hazardous chemicals for further research.

\section{REFERENCES}

[1] J.J. Spillane, Ekonomi Farmasi (Pharmaceutical Economics), Jakarta, Grasindo, Jakarta, 2010.

[2] M. Mikulic, Global Pharmaceutical Industry Statistics \& Facts, [Online]. zretrieved fromz; https://www.statista.com/topics/1764/globalpharmaceutical-industry, 2019.

[3] Global Business Report, Pertumbuhan Industri Farmasi (Growth of Pharmaceutical Industry), Indonesia Pharmaceuticals, 2015.

[4] Ministry of Industry, Sektor-sektor Manufaktur Andalan (Superior Manufacturing Sectors) [Online]. Retrieved from: https:// kemenperin.go.id, 2018.

[5] Team, Corporate Sustainability Report 20162018, Jakarta, Indonesia, Pharmaceutical Company, 2018.

[6] D.A. Garvin, How the Baldrige award really works, Harvard Business Review, vol. 69, no. 6, 1991, pp. 80-95.
[7] A. Griffith, Integrated management systems: a single management system solution for project control?, Journal of Engineering, Construction and Architectural Management, vol. 7, no. 3, 2000, pp. 232-40. DOI:10.1108/eb021148

[8] S. Karapetrovic, J. Jonker, Integration of standardized management systems: searching for a recipe and ingredients, Total Quality Management, vol. 14, no. 4, 2003, pp. 451459. DOI:10.1080/1478336032000047264

[9] J. Elkington, Cannibals with Forks, the Triple Bottom Line of Twentieth Century Business, in Teguh Sri Pembudi, CSR Sebuah Keharusan dalam Investasi Social (CSR as a Must in Social Investment). Jakarta, Pusat Penyuluhan Social (Social Extension Center, PUSENSOS) of the Ministry of Social Affairs of the Republic of Indonesia. La Tofi Enterprise, 2005.

[10] T. Artiach, D. Lee, D. Nelson, J. Walker, The determinants of corporate sustainability performance, Accounting \& Finance, vol. 50, no. 1,2010 , pp. 31-51. DOI:10.1111/j.1467629X.2009.00315.X

[11] J. Barney, Firm resources and sustained competitive advantage, journal of management, vol. 17, no. 1, 1991, pp. 99-120. DOI:

https://doi.org/10.1177/014920639101700108

[12] F.T. Bozbura, A. Beskese, C. Kahraman, Prioritization of human capital measurement indicators using fuzzy AHP, Expert Systems with Applications, vol. 32, no. 4, 2007, pp. 1100-1112. DOI:10.1016/j.eswa.2006.02.006

[13] B. Tjahjadi, Good Governance Fatamorgana in Indonesia and the Strategic Role of the Integrated Management System, Airlangga University, 2011.

[14] U.H. Inan, S. Gül, H. Yılmaz, A multiple attribute decision model to compare the firms' occupational health and safety management perspectives, Safety Science, vol. 91, 2016, pp.221-231.

DOI: https://doi.org/10.1016/j.ssci.2016.08.018

[15] N. Hamidi, M. Omidvari, M. Meftahi, The effect of integrated management system on safety and productivity indices: case study; Iranian cement industries, Safety Science, vol. 
50, 2012, pp.1180-1189. DOI: https://doi.org/10.1016/j.ssci.2012.01.004

[16] M. Gianni, K. Gotzamani, Management systems integration: lessons from an abandonment case, Journal of Cleaner Production, vol. 86, 2014, pp.265-276. DOI:10.1016/j.jclepro.2014.08.023

[17] G. Santos, F. Mendes, J. Barbosa, Certification and integration of management systems: the experience of Portuguese small and medium enterprises, Journal of Cleaner Production, vol. 19, no. 17-18, 2011, pp. 1965-1974. DOI:10.1016/j.jclepro.2011.06.017

[18] M.A. Massoud, N. Makarem, W. Ramadan, R. Nakkash, Environmental management practices in the lebanese pharmaceutical industries: implementation strategies and challenges, Environ Monit Assess, vol. 187, no. 107,2015 , pp. $1-10$. DOI:10.1007/s10661015-4290-3

[19] M. Gianni, K. Gotzamani, G. Tsiotras, Multiple perspectives on integrated management systems and corporate sustainability performance, Journal of Cleaner Production vol. 168, 2017, 1297-1311. DOI:10.1016/j.jclepro.2017.09.061

[20] L.Y. Han, L. Arokiasamy, J.T.K. Marn, A study on ethical customer management and organizational sustainability in pharmaceutical industry in Malaysia, Global Business and Management Research: An International Journal, vol. 11, no. 1, 2019, pp. 593-606.

[21] S. Faucher, Système Intégré De Management, Paris, Ed. AFNOR, 2006.

[22] C. Suditu, Positive and Negative Aspects regarding the Implementation of an Integrated Quality - Environmental - Health and Safety Management System, Annals of the Oradea University, vol. 6, no. 16, 2007, pp. 20132017.

[23] D. Hoyle, ISO 9000 Quality Systems Handbook, 6th edition, UK, Oxford, 2009.

[24] M.F. Rebelo, G. Santos, R. Silva, Integration of management systems: towards a sustained success and development of organizations. Journal of Cleaner Production. 127, 2016, pp. 96-111.

DOI: https://doi.org/10.1016/j.jclepro.2016.04.011

[25] J.A Santos, J.A.M. Dávila, L. Herrera, M. Nieto, Safety management system in TQM environments, Safety Science, vol. 101, 2017, pp.135-143.

DOI:

https://doi.org/10.1016/j.ssci.2017.08.019

[26] M.F. Rebelo, G. Santos, R. Silva, (2014) A generic model for integration of quality, environment and safety management system", The TQM Journal, vol. 26, no. 2, 2014 pp.143159.

[27] M. Rusko, J. Sablik, P. Marková*, M. Lach, S. Friedrich, Sustainable development, quality management system and environmental management system in Slovak republic, Procedia Engineering, vol. 69, 2014, pp. $486-$ 491.

DOI: https://doi.org/10.1016/j.proeng.2014.03.016

[28] M. Maletic, D. Maletic, J.J Dahlgaard, S.M. Dahlgaard-Park, B. Gomiscek, Do corporate sustainability practices enhance organizational economic performance?, 5International Journal of Quality and Service Sciences, vol. 7 no. 2/3, 2015, pp. 184-200. DOI:10.1108/IJQSS-022015-0025

[29] M. Maletic, D. Maletic, J.J Dahlgaard, S.M. Dahlgaard-Park, B. Gomiscek, Effect of Sustainability-oriented Innovation Practices on the Overall Organizational Performance: an Empirical Examination, Total Quality Management and Business Excellence, vol. 27, no. 10, 2015, pp. 1171-1190. DOI:10.1080/14783363.2015.1064767

[30] J.P.E. Souza, J.M. Alves, Lean-integrated management system: a model for sustainability improvement', Journal of Cleaner Production, vol. 172, 2017, pp. 2667-2682. DOI: https://doi.org/10.1016/j.jclepro.2017.11.144

[31] Agusty Ferdinand, Research Method of Management Science, UNDIP Press ISBN 979-704-254-5, 2014.

[32] D.J. Teece, G. Pisano, A. Shuen, A., Dynamic capabilities and strategic management, Strategic Management Journal. vol. 18, no. 7, 1997, pp. 509-533.

[33] P. Beske, Dynamic capabilities and sustainable supply chain management, 
International Journal of Physical Distribution \& Logistics Management, vol. 42, no. 4, 2012, pp. 372-387.

DOI:10.1108/09600031211231344

[34] A. Simon, L.H.P. Yaya, Improving innovation and customer satisfaction through systems integration. Industrial Management \& Data Systems, vol. 112, no. 7, 2012, 1026-1043. DOI:10.1108/02635571211255005

[35] M.M. Savino, E. Batbaatar, Investigating the resources for integrated management systems within resource-based and contingency perspective in manufacturing firms, Journal of Cleaner Production, vol. 104, 2015, pp. 392402. DOI: https://doi.org/10.1016/j.jclepro.2015.04.115

[36] A. Simon, M. Bernardo, How does Human Resources Management Influence the Implementation of Integrated Management Systems? Proceeding of 1st International Conference on Quality Engineering and Management, ICQEM, Guimaraes, Portugal, 2014, pp. 291-302.

[37] S.X. Zeng, J.J. Shi, G.X Lou, A synergetic model for implementing an integrated management system: an empirical study in China, Journal of Cleaner Production, vol. 15, no. $(8, \quad 2007$, pp. 1760-1767. DOI: https://doi.org/10.1016/j.jclepro.2006.03.007

[38] A.O. Paraschivescu, The advantages of the process of integrating quality management system, Economy Transdisciplinarity Cognition, vol. 19, 2016, pp. 48-55.

[39] M.F. Rebelo, Contribuic , ao para a estruturac ऽ ao de um modelo de sistema integrado de gest ao QAS, master thesis, Barcelos, Polytechnic Institute of Cávado and Ave, 2011.

[40] N.K.M. Khair, K.E. Lee, M. Mokhtar, C.T. Goh, (2015), Integrating responsible care into quality, environmental, health and safety management system: a strategy for Malaysian chemical industries, Journal of Chemical Health and Safety, vol. 25, 2018, pp. 10-18. DOI:

https://doi.org/10.1016/j.jchas.2018.02.003

[41] A. Simon, S. Karapetrovic, M. Casadesús, M., b. Difficulties and benefits of integrated management systems, Industrial Management \& Data Systems, vol. 112, no. 5, 2012, pp. 828-846. DOI:10.1108/02635571211232406

[42] M. Maletic, M. Podpecan, D. Maletic, ISO 14001 in a Corporate Sustainability Context: a Multiple Case Study Approach,. Management of Environmental Quality An International Journal, vol. 26, no. 6, 2015, pp. 872-890. DOI:10.1108/MEQ-08-2014-0129

[43] M.C.L. Luk, O. Yau, R.P.M. Chow, A. Tse, L.Y.M. Sin, Stakeholder orientation and business performance: the case of service companies in China, Journal of International Marketing, vol. 13, no. 1, 2005, pp. 89-110. DOI:10.1509/jimk.13.1.89.58536

[44] J.J. Tarí, J.F. Molina-Azorín, Integration of quality management and environmental management, TQM Journal, vol. 22, no. 6, 2010, pp. 687-701. DOI: $10.1108 / 17542731011085348$

[45] P. Sampaio, P. Saraiva, P. Domingues, Management systems: integration or addition?, International Journal of Quality \& Reliability Management, vol. 29, 2012, pp. 402-424. DOI:10.1108/02656711211224857

[46] D. Theodorou, P. Giannelos, Medical Laboratory Quality Systems - a Management Review, International Journal of Health Care Quality Assurance, vol. 28, no. 3, 2015, pp. 267-273.

DOI: http://dx.doi.org/10.1108/IJHCQA-04-20140039

[47] Environmental Management Systems Requirements (ISO 14001:2015), Switzerland, Geneva, International Organization for Standardization (ISO), 2015.

[48] A. Simon, S. Karapetrovic, M. Casadesús, Evolution of integrated management systems in Spanish firms, Journal of Cleaner Production, vol. 23, no. 1, 2012, pp. 8-19. DOI: https://doi.org/10.1016/j.jclepro.2011.10.025 